
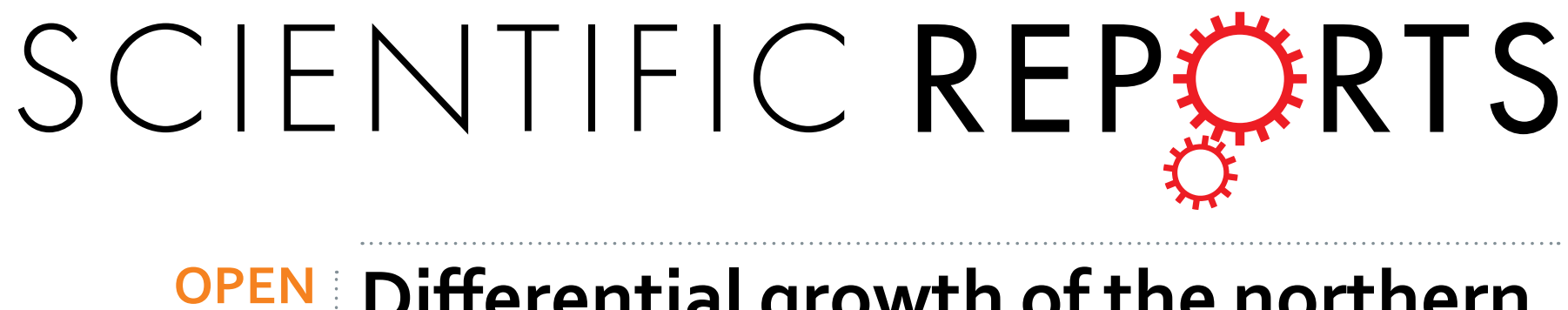

\title{
Differential growth of the northern Tibetan margin: evidence for oblique stepwise rise of the Tibetan \\ Plateau
}

Received: 16 September 2016

Accepted: 14 December 2016

Published: 24 January 2017

\author{
Fei Wang ${ }^{1,2}$, Wenbei Shi ${ }^{1}$, Weibin Zhang ${ }^{1}$, Lin Wu ${ }^{1}$, Liekun Yang ${ }^{1}$, Yinzhi Wang $^{1}$ \& Rixiang Zhu ${ }^{1}$
}

Models of how high elevations formed across Tibet predict: (a) the continuous thickening of a "viscous sheet"; (b) time-dependent, oblique stepwise growth; and (c) synchronous deformation across Tibet that accompanied collision. Our new observations may shed light on this issue. Here, we use ${ }^{40} \mathrm{Ar} /{ }^{39} \mathrm{Ar}$ and (U-Th)/He thermochronology from massifs in the hanging walls of thrust structures along the Kunlun Belt, the first-order orogenic range at the northern Tibetan margin, to elucidate the exhumation history. The results show that these massifs, and hence the plateau margin, were subject to slow, steady exhumation during the Early Cenozoic, followed by a pulse of accelerated exhumation during 40-35 Ma. The exhumation rate increases westward (from $\sim 0.22$ to 0.34 and $0.5 \mathrm{~mm} / \mathrm{yr}$ ). The twofold increase in exhumation in the western part $(0.5 \mathrm{~mm} / \mathrm{yr})$ compared to the eastern part suggests westward increases in exhumation and compressional stress along the Kunlun Belt. We relate these observations to the mechanisms responsible for the oblique stepwise rise of Tibet. After collision, oblique subduction beneath Kunlun caused stronger compressional deformation in the western part than in the eastern part, resulting in differential growth and lateral extrusion.

Although various models or hypotheses have been developed to describe the manner of Tibetan Plateau growth $^{1-5}$, the link between plateau growth and the geodynamics of intracontinental deformation remains at the center of debates. The ongoing convergence between India and Eurasia has produced double-thickness crust with thicknesses averaging $\sim 60 \mathrm{~km}$ over a distance $\sim 2000 \mathrm{~km}$ north of the plate boundary. The viscous sheet model $^{3}$ and the plastic, or oblique step-wise growth, model ${ }^{1,2}$ are based on different rheologies (continua vs. rigid blocks separated by faults) but predict a scenario of northward propagation of strain and younging ages. However, these hypotheses have been challenged recently. New studies show that the growth of the Tibetan Plateau may have begun in central Tibet and expanded to encompass most of Tibet, which is the central Tibet growth model ${ }^{4,6-8}$. Although the onset time of growth is still elusive, most studies suggest that the thickened crust and high topography in central Tibet and its northern margin were built up by $40-50 \mathrm{Ma}^{4-12}$ (Fig. 1), which is close to the commonly suggested collision time of $\sim 47-55 \mathrm{Ma}^{2,13-15}$. These data appear to contradict the notion of initiation and propagation of strain away from the collision boundary. However, recent re-dating of the initial collision suggests that the collision time should be moved to $\sim 65-60 \mathrm{Ma}$ ago $^{16-18}$. This proposed collision time is $\sim 30-25$ million years earlier than the onset of regional deformation in central Tibet and the northern margin, instead of being synchronous with it.

Cenozoic terrains along the northern margin of the Tibetan Plateau are considered to be the consequence of the far-field effects of continued Eurasia-India convergence ${ }^{2}$ and can be regarded as ideal locations to test the growth models. Characterized by high elevation accompanied by low relief in the western part and low elevation accompanied by high relief in the eastern part ${ }^{19}$, the Kunlun Belt is the first mountain belt defining the northern Tibetan margin. Composed mainly of Devonian to Early Triassic marine sediments, Jurassic and Cenozoic non-marine rocks ${ }^{20-22}$ and pre-Cenozoic granitoids (Fig. 2), the Kunlun Belt is considered, from a tectonic perspective, to be a part of the Paleozoic-Triassic collision belt and was rejuvenated during the Cenozoic EurasiaIndian collision and the growth of Tibetan Plateau ${ }^{11,23}$. A few low-temperature thermochronological studies have

${ }^{1}$ State Key Laboratory of Lithospheric Evolution, Institute of Geology and Geophysics, Chinese Academy of Sciences, Beijing 100029, China. ${ }^{2}$ CAS Center for Excellence in Tibetan Plateau Earth Sciences, Beijing 100029, China. Correspondence and requests for materials should be addressed to F.W. (email: wangfei@mail.iggcas.ac.cn) 


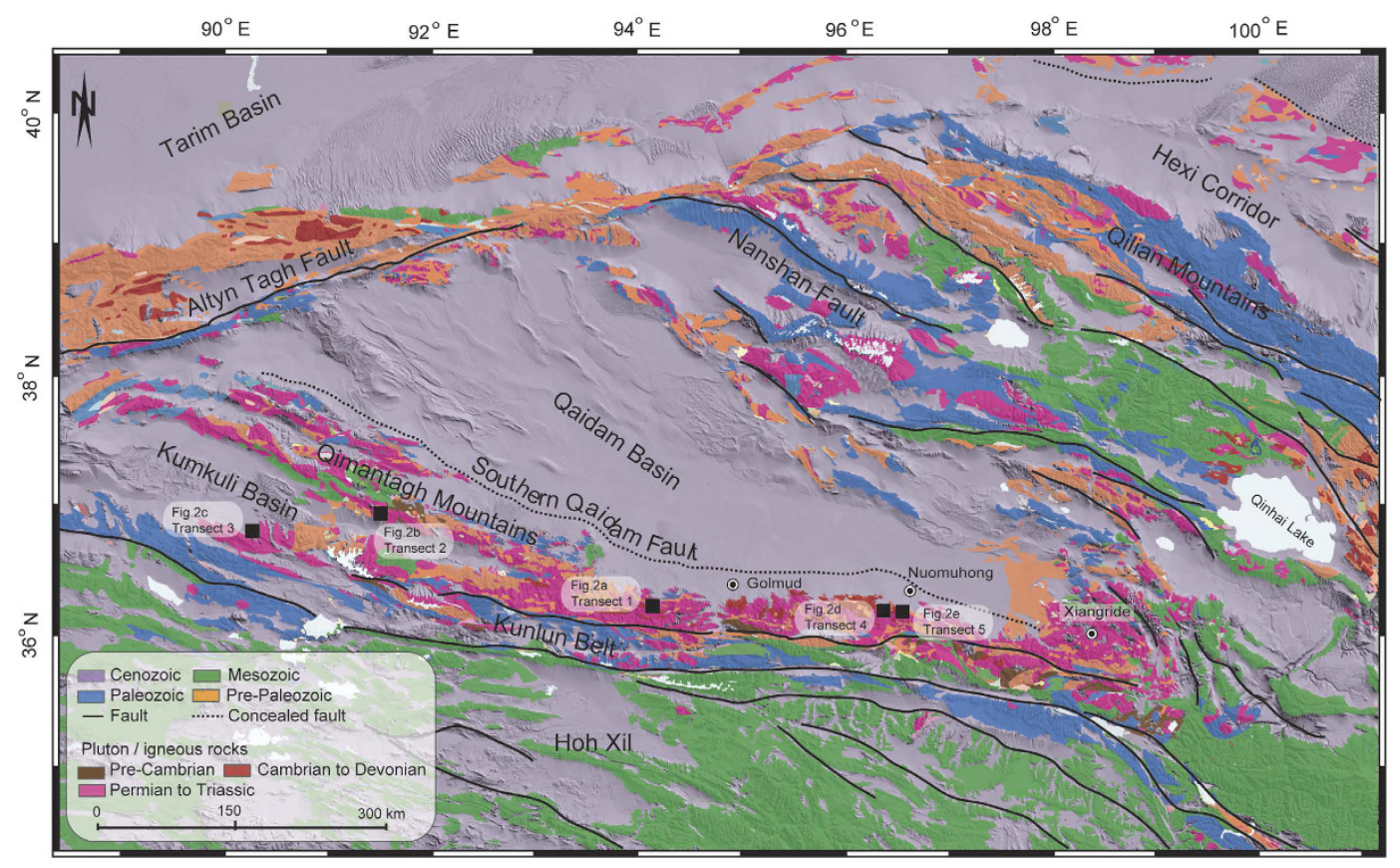

Figure 1. Simplified regional geologic map of the central and northern margin of the Tibetan Plateau and its adjacent regions. Tectonostratigraphic terranes are shown in the explanation. Figure was generated using MapInfo Professional [11.0.4], (URL: http://www.pbinsight.com/) and Global Mapper [17.2], (USL: http:// www.bluemarblegeo.com). The coordinate system is the World Geodetic System 1984 (WGS84). To facilitate comparisons with the eastern part of the Kunlun Belt, two transects from our previous work ${ }^{10}$ are shown as transect 4 and 5 .

been reported from the eastern part of the Kunlun Belt ${ }^{5,21,24-26}$, where a cooling history between $350-60^{\circ} \mathrm{C}$ was extracted. A rapid exhumation event and therefore the onset of deformation during the Cenozoic were then concluded to have occurred at approximately $30 \mathrm{Ma}^{24,25}$ or $40 \mathrm{Ma}^{5,10}$ in the eastern part of the Kunlun Belt. In contrast, low temperature geochronological studies are lacking, and existing constraints on the exhumation and cooling history of the western part of the Kunlun Belt are very poor. Therefore, although it is the first-order orogenic belt of the northern Tibetan margin and has great potential to reveal the evolution of the plateau, systematic research and direct evidence of the couplings between tectonics and surface processes are still lacking, and the modes of uplift and exhumation needs to be better quantitatively constrained.

To evaluate the timing and history of mountain-building in the Kunlun Belt, we date and model samples from three new vertical age-elevation transects from different parts of the Kunlun Belt (transect 1 comes from the middle part; transects 2 and 3 are found in the western part) (Fig. 2, Table S1). To facilitate comparisons with the eastern part of the Kunlun Belt, the original data from two of our previous transects in the eastern part (transects 4 and 5, Fig. 1) ${ }^{10}$ are also processed (Table S1) and modeled in this study. All of these transects are distributed evenly over a distance of $\sim 600 \mathrm{~km}$ along the Kunlun Belt and are located in the immediate hanging wall of the North Kunlun Fault (Fig. 1). Thus, the exhumation history of the range provides an important constraint on the manner of mountain-building along the northern Tibetan margin and can potentially inform models of the growth of the plateau.

\section{Results}

We present results using the K-feldspar ${ }^{40} \mathrm{Ar} /{ }^{39} \mathrm{Ar}$ and apatite (U-Th)/He thermochronological systems in Figs 3 and 4 and Supplementary Tables S3 and S4, respectively. A summary of the ages, including their sample locations, is provided in Table S1. Furthermore, the kinetics of argon and helium diffusion in these systems span a temperature window ranging from $\sim 350^{\circ} \mathrm{C}$ down to $\sim 60^{\circ} \mathrm{C}^{27,28}$ and allow us to investigate the thermal history of this part of the plateau margin in unprecedented detail.

K-feldspar ${ }^{40} \mathrm{Ar} /{ }^{39} \mathrm{Ar}$ analysis results. The results of $\mathrm{K}$-feldspar ${ }^{40} \mathrm{Ar} /{ }^{39} \mathrm{Ar}$ analysis of two samples from transects 1 (15kl03) and 2 (1335-2), respectively, are shown in Fig. 3 and Supplementary Table S3. Two K-feldspar samples exhibit flat age spectra (Fig. 3), defining good plateaus that account for $>80 \%$ of the total ${ }^{39}$ Ar released at high temperature steps, implying that rapid cooling occurred at these times (see Supplementary Information for details). The plateau ages are $232.5 \pm 1.4 \mathrm{Ma}$ (15kl03) and $234.6 \pm 1.2 \mathrm{Ma}$ (1335-2), which are similar to those reported by previous studies in the Kunlun Belt ${ }^{11,14,15}$. These massifs were rapidly exhumed during the early Late Triassic and are attributed to the orogeny of the Kunlun Belt, which was probably driven by the collision between the Songpan-Ganzi and Kunlun blocks ${ }^{11,29}$.

Conversely, the two age spectra display staircase shapes at the low temperature steps of the step-heating (Fig. 3). Although less than $20 \%$ of the total released ${ }^{39} \mathrm{Ar}$ resides within these low-temperature domains (Fig. 3), 

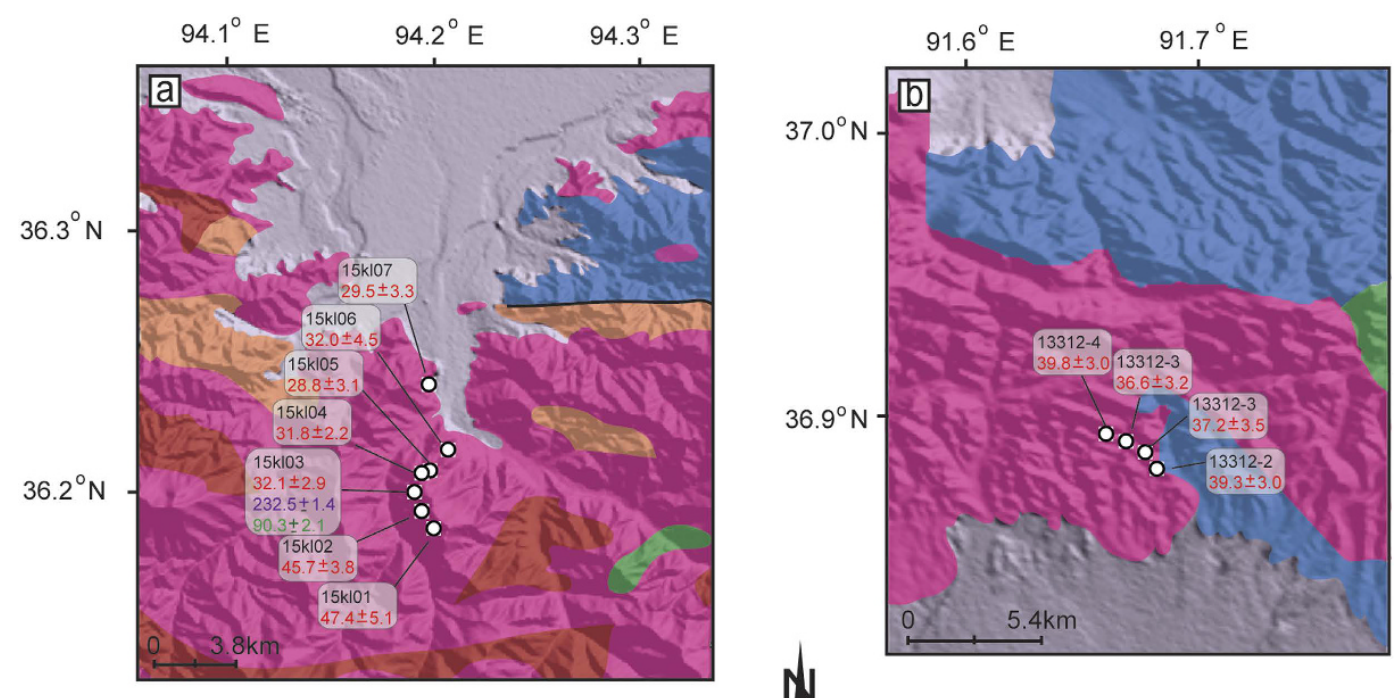

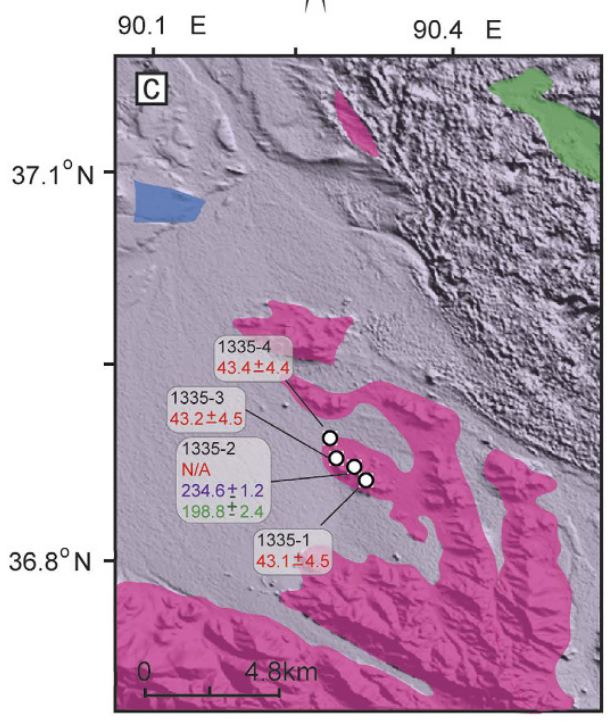

Figure 2. Geologic map of the transects of massifs sampled. Granitic massifs in the hanging wall of North Kunlun Fault zone. Figures were generated using MapInfo Professional [11.0.4], (URL: http://www.pbinsight. $\mathrm{com} /$ ) and Global Mapper [17.2], (USL: http://www.bluemarblegeo.com). The coordinate system is the World Geodetic System 1984 (WGS84). (a) The massif of transect $160 \mathrm{~km}$ to the west of Golmud; (b) Massif of transect 2 in the west part of Kunlun belt (Qimantagh); (c), Massif of transect 3 in the west part of Kunlun belt. Explanation of geologic units as in Fig. 1. Numbers in red are the (U-th)/He age in Ma, while numbers in purple and green are plateau and minimum ages of ${ }^{40} \mathrm{Ar} /{ }^{39} \mathrm{Ar}$ in $\mathrm{Ma}$, respectively.

the behavior ${ }^{30-33}$ of multi-diffusion domains within $\mathrm{K}$-feldspar suggests that these staircase spectra are the result of slow cooling and, therefore, record cooling ages between $\sim 350-150^{\circ} \mathrm{C}$. Their minimum ages of $198.8 \pm 2.4$ and $90.3 \pm 2.1 \mathrm{Ma}$ (Fig. 3, Table S1) reflect the final time when the samples passed the $\sim 150^{\circ} \mathrm{C}$ isotherm.

The ${ }^{40} \mathrm{Ar} /{ }^{39} \mathrm{Ar}$ thermochronologic data from K-feldspars imply that rocks now at the surface resided at or above temperature of $\sim 350^{\circ} \mathrm{C}$ during the early Late Triassic and $\sim 150^{\circ} \mathrm{C}$ during the late Cretaceous. These results place a maximum bound on total exhumation of $\sim 11 \mathrm{~km}$ since the middle Triassic and $\sim 5 \mathrm{~km}$ since the late Cretaceous, assuming a gradient of $30^{\circ} \mathrm{C} / \mathrm{km}^{5}$.

Apatite (U-Th)/He dating results. Ages from the apatite (U-Th)/He thermochronological system provide insight into the Cenozoic cooling history. Single apatite grains are analyzed by using the (U-Th)/He dating technique. The results are presented in Fig. 4 and Supplementary Table S4.

(U-Th)/He ages from transect 1 range from $47.4 \pm 4.5 \mathrm{Ma}$ at $4301 \mathrm{~m}$ down to $29.5 \pm 2.8 \mathrm{Ma}$ at $3125 \mathrm{~m}$ (Table S1, Fig. 4a), exhibiting a distinct age-elevation trend. The pattern of the trend shows an increase in the gradient at approximately $35 \mathrm{Ma}$, implying that accelerated exhumation began at this time. This observation is similar to those from our previous transects in the eastern part of the Kunlun Belt near Nuomuhong ${ }^{10}$, where a rapid exhumation starting around $35 \mathrm{Ma}$ was also recognized. In contrast, (U-Th)/He ages from transect 2 present a steep age-elevation relationship: the ages ranging from $39.8 \pm 3.0$ to $36.6 \pm 3.2 \mathrm{Ma}$ are dispersed over an elevation range 

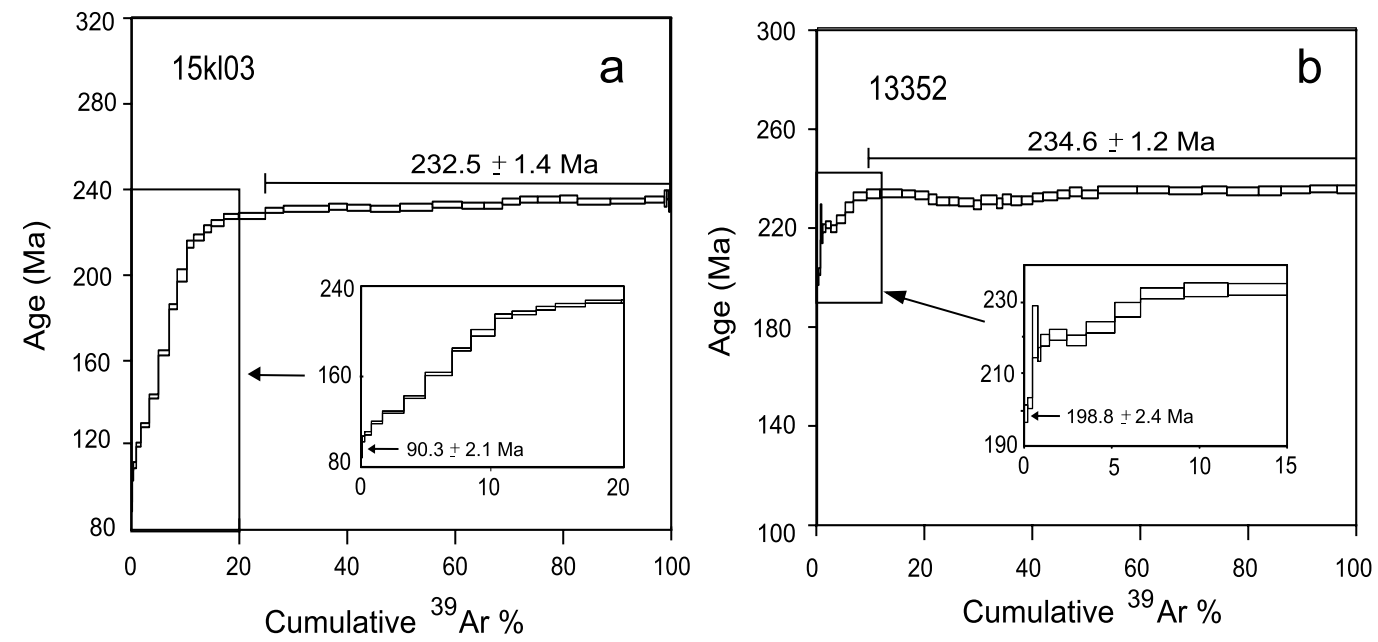

Figure 3. ${ }^{40} \mathrm{Ar} /{ }^{39} \mathrm{Ar}$ results of k-feldspars. Plateau ages are shown at high temperatures. Insets indicate the staircase age spectra of $\mathrm{K}$-feldspar at low temperatures with minimum ages labeled.
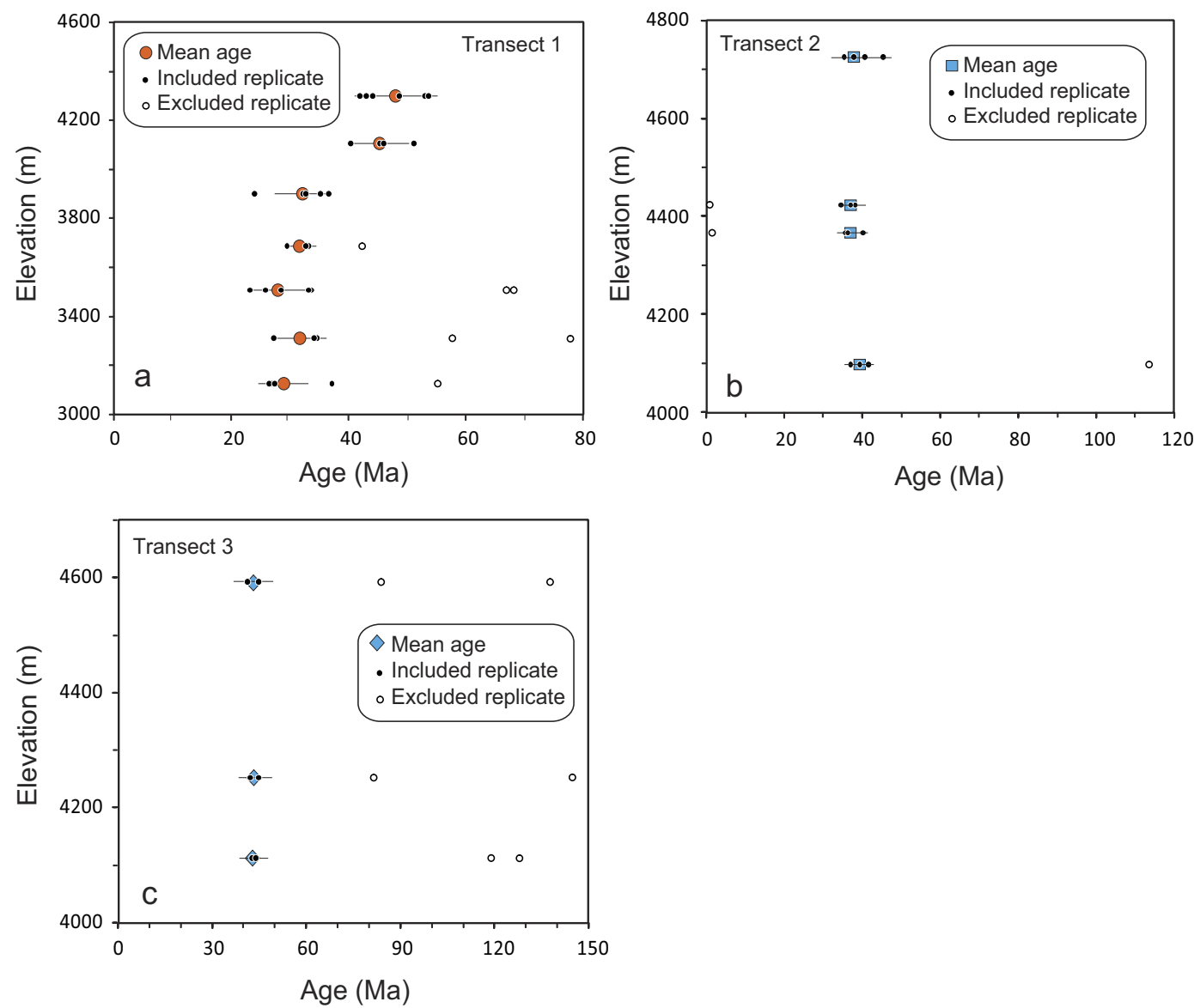

Figure 4. Age-elevation transects for (U-Th)/He thermochronologic data. Error bars denote $2 \sigma$ analytical uncertainties. (a), (U-Th)/He ages (circles) for transect 1; (b), (U-Th)/He ages (squares) for transect 2; (c), (U-Th)/He ages (diamonds) for transect 3. Filled symbols denote grain replicates included in the mean age determination. Open symbols denote excluded grain ages.

from $4727 \mathrm{~m}$ down to $4102 \mathrm{~m}$ (Fig. $4 \mathrm{~b}$ ), with an average age of $38.3 \pm 3.2 \mathrm{Ma}$. Similarly, three samples with almost the same age ( $43.1 \pm 4.5 \mathrm{Ma}, 43.2 \pm 4.5 \mathrm{Ma}$ and $43.4 \pm 4.4 \mathrm{Ma})$ from transect 3 are distributed over a vertical range of 4373-3892 m (Fig. 4c). The relatively small elevation ranges $(\sim 500-600 \mathrm{~m})$ from transect 2 and 3 , which are 


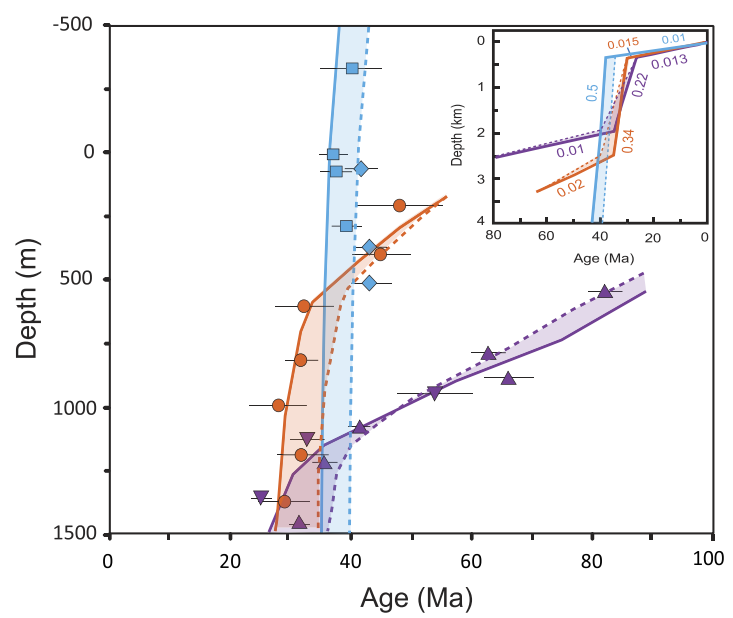

Figure 5. Composite age-depth transects comparing data with predictions of forward thermal models. Uncertainties are shown as $2 \sigma$. Inset shows color-matched time-depth histories of transects used in models. Numbers denote average exhumation rates in $\mathrm{mm} / \mathrm{yr}$ for each stage. Exhumation histories that represent acceleration starting $35 \mathrm{Ma}$ (solid lines) or $40 \mathrm{Ma}$ (dashed lines) are calculated. Shaded region between two histories represents of solutions between these time periods. Transects 4 (upper triangles) and 5 (lower triangles) from our previous work ${ }^{10}$ were modeled as well to make comparison. Time-depth history solution with acceleration starting $35 \mathrm{Ma}$ fits transect 1,4 and 5 perfectly, while the solution with acceleration starting $40 \mathrm{Ma}$ fits transect 2 and 3 well.

partially responsible for the age clustering, are insufficient to permit examination of age-elevation correlations for these massifs. Even so, given that the seven samples do not show any trend reflective of a slow exhumation in the age-elevation correlation suggest that transects 2 and 3 reflect parts of accelerated exhumation trend, although we do not see the break where it starts. This can be demonstrated using our new (U-Th)/He dates from detrital apatites (39.5-43.2 Ma, authors' paper under preparation) from Miocene growth strata in the Kumkuli intramontane basin, which suggest that the apatites eroded from the surrounding mountains (the western part of the Kunlun Belt and Qimantagh) have the same ages as transects 1 and 2. In addition, transect 2 exhibits very slightly negative correlation between age and depth (Fig. 5, Table S1), implying that this massif could have been tectonically tilted slightly. However, such an event is difficult to interpret on the basis of just this marginal correlation. Therefore, we conclude that the patterns of transects 2 and 3 most likely represent a monotonic cooling or an accelerated exhumation between $\sim 38$ and $\sim 43 \mathrm{Ma}$.

These results clearly reveal a picture of differential evolution of exhumation history along the Kunlun Belt. To compare directly, samples from each transect are normalized to the local elevation of a remnant erosion surface resolved from a 30-m resolution Digital Elevation Model (DEM) (Figs S1 and S2, see Supplementary Information), and plotted as age versus structural depth (Fig. S3, Fig. 5). To permit comparisons between different parts of the Kunlun Belt, two of our previous transects near Nuomuhong ${ }^{10}$, which are labeled as transects 4 and 5 in Fig. 1, are normalized to the local erosion surface (Table S1) and plotted and modeled in Fig. 5 as well. The five transects form three distinct age-depth trends in the age-depth plot (Fig. 5). Given various scenarios, forward thermal modeling was carried out on each trend, and the solutions are shown in Fig. 5 and Fig. S6. The data and modeling results demonstrate a tendency for uplift and exhumation to strengthen from east to west along the Kunlun Belt during Eocene time. The gentle slopes of transects 1, 4 and 5 imply that a very slow, constant exhumation (0.01-0.02 mm/yr) history was predominant in the Kunlun Belt during the late Cretaceous to early Paleogene (Fig. 5). Abrupt changes in the slopes of transects 1 (from 0.02 to $0.34 \mathrm{~mm} / \mathrm{yr}$ ), 4 and 5 (from 0.01 to $0.22 \mathrm{~mm} / \mathrm{yr}$ ) appear at $35 \mathrm{Ma}$, indicating that the onset of accelerated exhumation occurred $35 \mathrm{Ma}$ ago in the eastern and middle parts of the Kunlun Belt. Similarly, modeled results that form a steep slope at $\sim 40$ Ma in transects 2 and 3 demonstrate that rapid exhumation occurred at this time at a rate of $0.5 \mathrm{~mm} / \mathrm{yr}$ (Fig. 5). Although the difference ( $~ 5 \mathrm{Myr})$ in starting times of accelerated exhumation between the eastern and western parts of the Kunlun Belt is small and can be obscured by the uncertainties of the dates, the overall trend illustrated by all samples from transects 2 and 3 (where no samples yielded ages $<35 \mathrm{Ma}$ ) suggests that this difference may be meaningful and reflects the "true" situation. More evidences are discussed later that show that this inference is reasonable. The data from transects 2 and 3 do not record the abrupt change in slope, most likely because of the rapid exhumation which removed overlying rocks that would have recorded rapid slope changes in those transects. Nevertheless, the uppermost sample of this steep slope indicates the lower limit of rapid slope change in depth, which is $900 \mathrm{~m}$ and $1400 \mathrm{~m}$ higher than those of transect 1 and transects 4 and 5, respectively (Fig. 5). According to He kinetic and diffusion theory, the rapid slope change in the helium age-depth curve defines the start of the rapid motion of rocks towards the Earth's surface when pass the closure isotherm $\left(\sim 60^{\circ} \mathrm{C}\right)^{28}$. Therefore, our observations suggest that rapid uplift and exhumation occurred earlier in the western part than in the eastern part of the Kunlun Belt during the early Cenozoic. 


\section{Discussions}

Our new data suggest that the Kunlun Belt grew differentially from west to east during the Cenozoic. Specifically, uplift initiated at approximately $40 \mathrm{Ma}$ in the western part and at approximately $35 \mathrm{Ma}$ in the eastern part. Exhumation rates of $0.22 \mathrm{~mm} / \mathrm{yr}$ in the eastern part, $0.34 \mathrm{~mm} / \mathrm{yr}$ in the middle part and $0.5 \mathrm{~mm} / \mathrm{yr}$ in the western part suggest a westward increase in uplift, under the logical assumption that the different parts of the Kunlun Belt experienced the same climatic conditions. Given a uniform geologic setting, the westward strengthening of uplift and exhumation suggest that lateral compression increased in strength from east to west along the Kunlun Belt. The modeled exhumation rates (Fig. 5) imply that the western part experienced compressive forces twice as strong as those experienced by the eastern part.

A growing body of evidence indicates that the regional deformation was stronger and initiated earlier in the western part than in the eastern part along the Kunlun Belt during early Cenozoic. Rapid exhumation of the eastern part of the Kunlun Belt at approximately $30 \mathrm{Ma}$ is inferred from accelerated cooling determined from feldspar multi-domain diffusion modeling ${ }^{24,25}$. Previous (U-Th)/He data revealed a rapid exhumation event beginning at approximately $35 \mathrm{Ma}$ in the eastern part of the Kunlun Belt ${ }^{5}$. Apatite and zircon (U-Th)/He and apatite fission-track ages along the strike of the eastern part of the Kunlun Fault show that exhumation rates increase eastward, from 30-25 Ma near Golmud to 20-15 Ma near Xiangride ${ }^{34}$ (Fig. 1).

The initiation of sedimentation in the Kumkuli basin since the middle Eocene suggests that rapid exhumation started $\sim 40 \mathrm{Ma}$ in the western part of the Kunlun Belt ${ }^{35}$. Detrital apatite (U-Th)/He ages that cover a range of 39.5-43.2 Ma (authors' paper under preparation) from Miocene growth strata in the Kumkuli Basin also indicate that rapid exhumation started at approximately $40 \mathrm{Ma}$ in the western part. Sedimentation rates in the adjacent Qaidam Basin increased rapidly during the period between $40-36.6 \mathrm{Ma}^{25,36-38}$. Growth strata that were deposited approximately $40 \mathrm{Ma}$ are extensively preserved in the peripheral areas of the western Qaidam Basin ${ }^{35,39,40}$ implying rapid denudation of the surrounding mountains. A detailed study of the magnetostratigraphy of the lower Tertiary sedimentary sequence in the western Qaidam Basin shows that the sedimentation initiated sometimes before $40 \mathrm{Ma}^{41}$. The main depocenter of the Qaidam Basin shifted from the western part to the eastern part during the late Cenozoic ${ }^{35}$, suggesting that the provenance of sedimentation moved from west to east in the surrounding mountains. Regional seismic reflection profiles across the Qaidam Basin reveal that a progressive shift in crustal thickening mechanisms: crustal shortening decreases from $>48 \%$ in the west to $<1 \%$ in the east during the early Cenozoic $^{42}$. In the Hoh Xil basin, immediately south of the study area, there was rapid sedimentation at approximately $40-35 \mathrm{Ma}^{4}$. A recent review that investigated various lines of evidence, including deformation, faulting, the results of basin research, paleomagnetic declination anomalies and thermochronology, concluded that growth and deformation of the northern Tibetan margin began at 50-40 $\mathrm{Ma}^{11,12}$.

Two end-member models of how the Tibetan Plateau formed are: (a) diffuse crustal thickening of a viscous sheet, with shear on vertical planes playing a subsidiary role (i.e., the viscous sheet model) ${ }^{3}$, and (b) localized shear between rigid lithospheric blocks (i.e., oblique stepwise growth model) ${ }^{1}$. Both models predict time-dependent, northward progression of strain and deformation that is initially concentrated at the plate boundary and then propagates in time away from that boundary as topographic stresses begin to favor deformation at greater distances from the plate boundary.

Recently, a new mechanism for Tibetan Plateau growth has been proposed, namely the central Tibet growth model, although when and how are still in dispute. The main feature of this model is that the region of high topography initiated in central Tibet and the lithospheric stresses propagated north and south from this high topography outward ${ }^{4,6,7,8,11}$. Although the onset time of growth remains controversial, most studies suggest a scenario in which the high topography in central Tibet and the northern Tibetan margin was built up by $40-50 \mathrm{Ma}^{4,6,7,8,11,12}$.

The timing of collision between India and Eurasia has been disputed over the past several decades but is crucial for understanding the far-field effects of the collision. The commonly suggested age of collision of $47-55 \mathrm{Ma}^{2,13,15}$ implies an immediate response to the collision in central and northern Tibet. However, several recent studies suggest that the collision between India and Eurasia may have occurred during the early Paleocene $(\sim 65-60 \mathrm{Ma})^{16-18}$, 30-20 Myr earlier than the initiation of regional scale deformation across the central and northern Tibet. These latest observations imply that the propagation of the far-field effects of the collision to the northern margin was much slower than previously thought ${ }^{2,5}$. (U-Th)/He ages from the North Qilian Shan suggest that rapid exhumation extended slowly northward, reaching as far as the Hexi Corridor by the late Miocene $\left(\sim 10 \mathrm{Ma}^{43}\right)$, and apatite fission track ages from the Liupan Shan indicate that rapid exhumation did not begin until $\sim 8 \mathrm{Ma}^{44}$. Although a complete picture of how the deformation crossed the Tibetan Plateau remains elusive, diachronous initial growth in different portions of the plateau (40 Ma ago in the east and $20 \mathrm{Ma}$ ago in the west ${ }^{6} ; 40 \mathrm{Ma}$ ago in the north ${ }^{4}$; $30 \mathrm{Ma}$ ago in the southeast ${ }^{45}$ ) imply that strain propagation may have had a key role in the evolution of Tibet.

The viscous sheet model predicts progressive northward migration of the associated crustal thickening and therefore synchronous uplift and uniform force at the frontline in the propagation direction after the rigid "indenter" represented by India converged with the weaker Eurasian lithosphere. However, this is not consistent with our observations of diachronous deformation with different intensities across the northern Tibetan margin. In addition, the strain generated by edge tractions in the thin viscous sheet model is insufficient to generate faulting in northern Tibet ${ }^{5}$.

Our thermochronologic data and modeling results from the Kunlun Belt support the oblique step-wise growth mechanism. Although how and when the stress propagated across the Tibet is called into question by new deformation evidence from central Tibet ${ }^{4,6-8,12}$, the notion of the oblique stepwise growth model $^{2}$, i.e., the oblique rise of Tibet and lateral extrusion of the thickened crust, is consistent with our thermochronologic results along the Kunlun Belt. This model describes a picture of oblique subduction after collision. Oblique subduction of the Asian lithospheric mantle plays a key role that involves both lateral extrusion and crustal thickening ${ }^{2}$. It can account for the markedly asymmetric growth of relief toward the east and the eastward extrusion observed in northeastern and eastern Tibet ${ }^{45}$. Far-field impacts on the northern Tibetan margin initially developed approximately 
40-35 Ma. Oblique subduction of the Qaidam block beneath the Kunlun Belt to depth of approximately 200 to $300 \mathrm{~km}^{2}$ resulted in sinistral slip along the Kunlun and North Kunlun Faults and crustal thickening. A stronger stress was created in the western than in the eastern part of the Kunlun Belt due to the northeast-southwest oblique compression, resulting in an eastward decrease in uplift and exhumation along the Kunlun Belt (Fig. 5). The movement along lithospheric faults resulted in eastward extrusion of the Tibetan Plateau, followed by a major compression event in the late Eocene. Consequently, the present-day Kunlun Belt contains a highland with low relief in the western part and a lowland with high relief in the eastern part.

Our results support the temporal development predicted by the central Tibetan growth model. This model suggests a scenario of plateau growth in central Tibet and propagation to the northern Tibetan margin by $40-50 \mathrm{Ma}$ that is consistent with our observations along the Kunlun Belt ${ }^{4,6-8,12}$. The growth of central Tibet and northward stress propagation are associated with folding and thrusting that resulted from subduction of the Indian lithosphere underneath the Tibetan plateau ${ }^{4,6-8}$. Northward thrusting from central Tibet is obliquely oriented $^{2,4,6,8}$, causing an eastward decrease in compressional stress along the Kunlun Belt.

\begin{abstract}
Methods
${ }^{40} \mathrm{Ar} /{ }^{39} \mathrm{Ar}$ geochronology. Characterized by complicated microstructures that serves as domains with different sizes, argon retention properties and closure temperatures ${ }^{30,31,46}, \mathrm{~K}$-feldspars are potentially able to record ${ }^{40} \mathrm{Ar} /{ }^{39} \mathrm{Ar}$ ages of closure temperatures ranging from 350 down to $150{ }^{\circ} \mathrm{C}$ as they $\mathrm{coo}^{27,47}$, and thermal histories can consequently be extracted ${ }^{30-33,48}$. A high resolution (36-40 steps) step-heating technique was applied from 450 to $1300^{\circ} \mathrm{C}$ in ${ }^{40} \mathrm{Ar} /{ }^{39} \mathrm{Ar}$ analysis to reveal the argon distributions within the $\mathrm{K}$-feldspar grains in as much detail as possible (Table S3). K-feldspars were carefully inspected to meet the criteria and requirements of thermochronology using the ${ }^{40} \mathrm{Ar} /{ }^{39} \mathrm{Ar}$ method ${ }^{27,48}$. The sample processing and laboratory procedures involved in ${ }^{40} \mathrm{Ar} /{ }^{39} \mathrm{Ar}$ analysis are described by Wang et al. ${ }^{31}$. Ages were calculated against the international standard YBCs sanidine $\left(29.286 \pm 0.045 \mathrm{Ma}^{49}\right)$. The experiments were conducted on an MM5400 mass spectrometer; plateau ages were calculated using adjacent ages of step-heating that agreed within a range of $2 \sigma$. A complete discussion of sample preparation and analytical procedures can be found in the Supplementary Information.
\end{abstract}

(U-Th)/He geochronology. See the Supplementary Information for sample preparation. In principle, clear, euhedral apatite grains longer than $130 \mu \mathrm{m}$ and wider than $75 \mu \mathrm{m}$ were used for (U-Th)/He dating. Each apatite grain was inspected carefully under a high-power microscope to eliminate those containing impurities and inclusions. Needle-like, fragmentary, subhedral, rounded or zoned apatite grains were excluded as well. After this selection process, each selected apatite grain was enclosed in a $1 \mathrm{~mm} \times 1 \mathrm{~mm}$ platinum capsule and moved one after another into a well in a stainless-steel disk for He measurement using an Alphachron MK II noble gas mass spectrometer. Each grain was heated twice at $900^{\circ} \mathrm{C}$ by a diode laser, each time for $10 \mathrm{~min}$, to extract the He completely as possible. The abundance of ${ }^{4} \mathrm{He}$ was determined using the isotope dilution technique. The ${ }^{3} \mathrm{He}$ spike used is calibrated daily against an independent ${ }^{4} \mathrm{He}$ standard tank. The uncertainty of the ${ }^{4} \mathrm{He}$ measurements averaged less than $2 \%$. After completion of the He measurements, the degassed apatite grains were removed and prepared for $U$ and Th measurements. After being removed from the capsule and placed in a beaker, each apatite was dissolved in $25 \mu \mathrm{L}$ of a liquid reagent made up of $50 \% \mathrm{HNO}_{3}$ spiked with ${ }^{235} \mathrm{U}$ and ${ }^{230} \mathrm{Th}$. The beakers were subjected to ultrasound vibrations until the apatite crystals had dissolved completely. Finally, the liquid reagent was diluted to $5 \% \mathrm{HNO}_{3}$ and analyzed for $\mathrm{U}$ and Th abundances by using a Thermo Fisher X-Series II ICP-MS. As determined by averaging replicate analyses of spiked standard solutions, the analytical precisions of the measured ${ }^{235} \mathrm{U} /{ }^{238} \mathrm{U}$ and ${ }^{230} \mathrm{Th} /{ }^{232} \mathrm{Th}$ ratios were $0.8 \%$ and $0.5 \%$, respectively. A series of Durango standard grains was analyzed between measurements of sample grains for monitoring the whole experimental protocol. Application of (U-Th)/He methods at IGGCAS yielded an averaged Durango apatite age of $32.24 \pm 1.01 \mathrm{Ma}^{50}$ with an internal precision $(1 \sigma)$ of $1.5 \%$. This age is quite consistent with the recommended age $e^{10,50}$. A detailed description of analytical procedures can be found in the Supplementary Information.

Forward modeling. A one-dimensional thermal model was utilized for forward modeling of the thermal response to exhumation. Various exhumation histories were imposed, subject to the constraint imposed by a thermal gradient of $30^{\circ} \mathrm{C} / \mathrm{km}$ (see the Supplementary Information), and subject to a constant surface temperature of $10^{\circ} \mathrm{C}$. Thermal history solutions for each transect were obtained using a constant temperature offset $\left(30^{\circ} \mathrm{C} /\right.$ $\mathrm{km}$ ) model in QTQt v.5.3.0 ${ }^{51}$, and the median thermal history was used for the transect. The detailed modeling procedure can be found in Gallagher et al. ${ }^{51}$. Samples along a transect are used to calculate model helium ages using the helium diffusion kinetics from Flowers et al. ${ }^{52}$ (radiation damage model RDAMM). We seek a series of preferred model fits that faithfully represent most of the sample ages, i.e., the basic trend of the data. A detailed description of the modeling procedure can be found in the Supplementary Information.

\title{
References
}

1. Tapponnier, P., Peltzer, G., Le Dain, A. Y., Armijo, R. \& Cobbold, P. Propagating extrustion tectonics in Asia: new insights from simple experiments with plasticine. Geology 10,611-616 (1982).

2. Tapponnier, P. et al. Oblique stepwise rise and growth of the Tibet Plateau: Science 294, 1671-1677 (2001).

3. England, P. C. \& Houseman, G. A. Finite strain calculations of continental deformation 2. comparison with the India-Asia collision zone. Journal of Geophysical Research 91, 3664-3676 (1986).

4. Wang, C. et al. Constraints on the early uplift history of the Tibetan Plateau. Proc. Natl Acad. Sci. USA 105, 4987-4992 (2008).

5. Clark, M. K., Farley, K. A., Zheng, D., Wang, Z. \& Duvall, A. R. Early Cenozoic faulting of the northern Tibetan Plateau margin from apatite (U-Th)/He ages. Earth and Planetary Science Letters 296, 78-88 (2010).

6. Kapp, P., DeCelles, P. G., Gehrels, G. H., Heizler, M. \& Ding, L. Geological records of the Lhasa-Qiangtang and Indo-Asian collisions in the Nima area of central Tibet. GAS Bulletin 119, 917-932 (2007).

7. Rohrmann, A. et al. Thermochronologic evidence for plateau formation in central Tibet by 45 Ma. Geology 40, 187-190 (2012). 
8. Ding L. et al. The Andean-type Gangdese Mountains: Plaeoelevation record from the Paleocene-Eocene Linzhou Basin. Earth and Planetary Science Letters 392, 250-264 (2014).

9. Chung, S. et al. Diachronous uplift of the Tibetan plateau starting 40 Myr ago. Nature 394, 769-773 (1998).

10. Wang, F. et al. Relief history and denudation evolution of the northern Tibet margin: Constraints from ${ }^{40} \mathrm{Ar} /{ }^{39} \mathrm{Ar}$ and $(\mathrm{U}-\mathrm{Th}) / \mathrm{He}$ dating and implications for far-field effect of rising plateau. Tectonophysics 675, 196-208 (2016).

11. Jolivet, M. et al. Mesozoic and Cenozoic tectonics of the northern edge of the Tibetan plateau: fission-track constraints. Tectonophysics 343, 111-134 (2001).

12. Yuan, D. et al. The growth of northeastern Tibet and its relevance to large-scale continental geodynamics: A review of recent studies. Tectonics 32, 1-13 (2013).

13. Houseman, G. \& England, P. A lithosphericthickening model for the Indo-Asian collision. In The tectonic evolution of Asia (eds Yin, A. \& Harrison, T. M.) 3-17 (Cambridge University Press, 1996).

14. Rowley, D. B. Age of initiation of collision between India and Asia: a review of stratigraphic data. Earth Planet. Sci. Lett. 145, 1-13 (1996).

15. Lippert, P. C., van Hinsbergen, D. J. J. \& Dupont- Nivet, G. Early Cretaceous to present latitude of the central proto-Tibetan Plateau: A paleomagnetic synthesis with implications for Cenozoic tectonics, paleogeography, and climate of Asia. In Toward an improved understanding of uplift mechanisms and the elevation history of the Tibetan Plateau (eds Nie, J. et al.) 1-21 (Geological Society of America Special Paper 507, 2014).

16. Ding, L., Kapp, P. \& Wan, X. Q. Paleocene- Eocene record of ophiolite obduction and initial India-Asia collision, south central Tibet: Tectonics 24, TC3001 (2005).

17. Wu, F. Y. et al. Zircon U-Pb and Hf isotopic constraints on the onset time of India- Asia collision: American Journal of Science 314, 548-579 (2014)

18. Hu, X., Garzanti, E., Moore, T. \& Raffi, I. Direct stratigraphic dating of India-Asia collision onset at the Selandian (middle Paleocene, $59 \pm 1 \mathrm{Ma})$. Geology 43, 859-862 (2015).

19. Wang, G., Yang, W., Ma, H. \& Wang, A. Comparing of the tectonic uplift since Late Cenozoic between the East and West Kunlun Mountains. Earth Science Frontiers 12, 157-166 (2005).

20. Liu, Y. et al. ${ }^{40} \mathrm{Ar} /{ }^{39} \mathrm{Ar}$ mineral ages from basement rocks in the Eastern Kunlun Mountains, NW China, and their tectonic implications. Tectonophysics 398, 199-224 (2005).

21. Dai, J., Wang, C., Hourigan, J. \& Santosh M. Multi-stage tectono-magmatic events of the Eastern Kunlun Range, northern Tibet: Insights from $\mathrm{U}-\mathrm{Pb}$ geochronology and $(\mathrm{U}-\mathrm{Th}) / \mathrm{He}$ thermochronology. Tectonophysics 599, 97-106 (2013).

22. Li, W. et al. Plaeozoic evolution of the Qimantagh magmatic arcs, Eastern Kunlun Mountains: Constraints from zircon dating of granitoids and modern river sands. Journal of Asian Earth Sciences 77, 183-202 (2013).

23. Matte, P. et al. Tectonics of Western Tibet, between the Tarim and Indus. Earth and Planetary Science Letters 14, 311-330 (1996).

24. Mock, C., Arnaud, N.\& Cantagrel, J.-M. An early unroofi ng in northeastern Tibet? Constraints from ${ }^{40} \mathrm{Ar} /{ }^{39} \mathrm{Ar}$ thermochronology on granitoids from the eastern Kunlun range (Qinghai, NW China): Earth and Planetary Science Letters 171, 107-122 (1999).

25. Wang, F. et al. Onset timing of signifi cant unroofi ng around Qaidam Basin, northern Tibet, China: Constraints from $40 \mathrm{Ar} / 39 \mathrm{Ar}$ and FT thermochronology on granitoids. Journal of Asian Earth Sciences 24, 59-69 (2004).

26. Yuan, W., Dong, J., Wang S. \& Carter, A. Apatite fission track evidence for Neogene uplift in the eastern Kunlun Mountains, northern Qinghai-Tibet Plateau, China. Journal of Asian Earth Sciences 27, 847-856 (2006).

27. Lovera, O. M., Grove, M. \& Harrison, T. M. Systematic analysis of K-feldspar ${ }^{40} \mathrm{Ar} /{ }^{39} \mathrm{Ar}$ step heating results II: Relevance of laboratory argon diffusion properties to nature. Geochimica et Cosmochimica Acta 66, 237-1255 (2002).

28. Reiners, P. W. \& Brandon, M. T. Using thermochronology to understand orogenic erosion. Annu. Rev. Earth Planet. Sci. 34, 419-466 (2006).

29. Yang, J. et al. The paleo-Tethyan volcanism and plate tectonic regime in the A'nyemaqen region of East Kunlun, northern Tibet Plateau. Acta Petrologica et Mineralogica 24, 369-380 (2005).

30. Cassata, W. S. \& Renne, P. R. Systematic variations of argon diffusion in feldspars and implications for thermochronometry. Geochimica et Cosmochimica Acta 112, 251-287 (2013).

31. Wang, F. et al ${ }^{40} \mathrm{Ar} /{ }^{39} \mathrm{Ar}$ geochronology of the North China and Yangtze Cratons: New constraints on Mesozoic cooling and cratonic destruction under East Asia. Journal of Geophysical Research 119, 3700-3721 (2014a).

32. Lovera, O. M., Richter, F. M. \& Harrison, T. M. The ${ }^{40} \mathrm{Ar} /{ }^{39} \mathrm{Ar}$ thermochronology for slowly cooled samples having a distribution of diffusion domain sizes. Journal of Geophysical Research 94, 17917-17935 (1989).

33. Lovera, O. M., Richter, F. M. \& Harrison, T. M. Diffusion domains determined by ${ }^{39}$ Ar released during step heating. Journal of Geophysical Research 96, 2057-2069 (1991).

34. Duvall, A. R. et al. Low-temperature thermochronometry along the Kunlun and Haiyuan Faults, NE Tibetan plateau: evidence for kinematic change during late-stage orogenesis. Tectonics 32, 1190-1211 (2013).

35. Meng, Q. \& Fang, X. Cenozoic tectonic development of the Qaidam Basin in the northeastern Tibetan Plateau In Investigations into the Tectonics of the Tibetan Plateau (eds Burchfi el, B. C. \& Wang, E.) 1-24 (Geological Society of America Special Paper 444, 2008).

36. Me'tivier, F. Volumes se'dimentaires et bilans de masse en Asie pendant le Ce'nozor"que. PhD Thesis, University of Paris VII, 255-266 (1996).

37. Cui, J. W. et al. Altyn Fault System, Geology Press, Beijing, p. 52-76 (1999).

38. Chen, W.-P., Chen, C.-Y. \& Nabelek, J. L. Present-day deformation of the Qaidam basin with implications for intra-continental tectonics. Tectonoghys 305, 165-181 (1998).

39. Bally, A. et al. Notes on sedimentary basins in China. Reports of the American Sedimentary Basins Delegation to the People's Republic of China. U.S. Geol. Surv. 86-327 (1986).

40. Yin, A. et al. Cenozoic tectonic evolution of Qaidam basin and its surrounding regions (Part 1): the southern Qilian Shan-Nan Shan thrust belt and northern Qaidam basin. Geol. Soc. Am. Bull. 120, 813-846 (2008).

41. Sun, J. et al. Synchronous turnover of flora, fauna, and climate at the Eocene-Oligocene Boundary in Asia. Scientific Reports 4, 7463 (2014).

42. Yin, A. et al. Cenozoic evolution and tectonic reconstruction of the Qaidam Basin: evidence from seismic frofile. Journal of Geomechanics 13, 193-211 (2007).

43. Zheng, D. et al. Erosion, fault initiation and topographic growth of the North Qilian Shan (northern Tibetan Plateau). Geosphere 6, 937-941 (2010).

44. Zheng, D. et al. Rapid exhumation at $8 \mathrm{Ma}$ on the Liupan Shan thrust fault from apatite fission-track thermochronology: implications for growth of the northeastern Tibetan Plateau margin. Earth Planet. Sci. Lett. 248, 198-208 (2006).

45. Wang, E. et al. Two-phase growth of high topography in eastern Tibet during the Cenozoic. Nature Geoscience 5, 640-645 (2012).

46. Parsons, I. et al. Eight-phase alkali feldspars: low-temperature cryptoperthite, peristerite and multiple replacement reactions in the Klokken intrusion. Contributions to Mineralogy and Petrology 165, 931-960 (2013).

47. Wartho, J. A. et al. Direct measurement of Ar diffusion profiles in a gem-quality Madagascar K-feldspar using the ultra-violet laser ablation microprobe (UVLAMP), Earth and Planetary Science Letters 170, 141-153 (1999).

48. Lee, J. K. W. Multipath diffusion in geochronology. Contributions to Mineralogy and Petrology 120, 60-82 (1995).

49. Wang, F. et al. YBCs: A new standard for ${ }^{40} \mathrm{Ar} /{ }^{39} \mathrm{Ar}$ dating. Chemical Geology 388, 87-98 (2014b). 
50. Wu, L. et al. Cenozoic exhumation history of Sulu terrane: Implications from (U-Th)/He thermochrology. Tectonophysics 672-673, $1-15$ (2016).

51. Gallagher, K., Stephenson, J., Brown, R., Holmes, C. \& Fitzgerald, P. Low temperature thermochronology and modeling strategies for multiple samples 1: Vertical profiles. Earth and Planetary Science Letters 237, 193-208 (2005).

52. Flowers, R. M., Ketcham, R. A., Shuster, D. L. \& Farley, K. A. Apatite $(\mathrm{U}-\mathrm{Th}) / \mathrm{He}$ thermochronometry using a radiation damage accumulation and annealing model. Geochemica et Cosmochimica Acta 73, 2347-2365 (2009).

\section{Acknowledgements}

This study is supported by the "Strategic Priority Research Program" of the Chinese Academy of Science (XDB03020203), Natural Science Foundations of China (41673015, 41025010, 41221002). The authors thank Bihong Fu, Pinlong Shi for their kind help in field work. We are very indebt to two reviewers as they raised constructive discussions. Our final thanks are for the anonymous editor of the journal, for his support and kind help in the review round.

\section{Author Contributions}

F.W. conducted field work and collected samples together with W.S., W.Z. and L.Y., W.S. and L.Y. were responsible for ${ }^{40} \mathrm{Ar} /{ }^{39} \mathrm{Ar}$ analyses and ages; L.W. and Y.W. were responsible for (U-Th)/He dating. F.W. carried out thermal modeling. F.W. and R.Z. designed the study and wrote the manuscript; all authors discussed interpretations and commented on the manuscript.

\section{Additional Information}

Supplementary information accompanies this paper at http://www.nature.com/srep

Competing financial interests: The authors declare no competing financial interests.

How to cite this article: Wang, F. et al. Differential growth of the northern Tibetan margin: evidence for oblique stepwise rise of the Tibetan Plateau. Sci. Rep. 7, 41164; doi: 10.1038/srep41164 (2017).

Publisher's note: Springer Nature remains neutral with regard to jurisdictional claims in published maps and institutional affiliations.

(c) (i) This work is licensed under a Creative Commons Attribution 4.0 International License. The images or other third party material in this article are included in the article's Creative Commons license, unless indicated otherwise in the credit line; if the material is not included under the Creative Commons license, users will need to obtain permission from the license holder to reproduce the material. To view a copy of this license, visit http://creativecommons.org/licenses/by/4.0/

(C) The Author(s) 2017 